\title{
An investigation between intellectual capital and investment opportunity
}

\author{
Shiva Tavakoli ${ }^{*}$ and Ali Alikhani
}

Department of Management and Accounting, North Branch, Islamic Azad University, Tehran, Iran

\section{H R O N I C L E}

Article history:

Received June 28, 2013

Received in revised format

19 October 2013

Accepted 23 October 2013

Available online

December 92013

Keywords:

Intellectual capital

Investment opportunity

Tehran Stock Exchange

\section{A B S T R A C T}

This paper presents an empirical investigation to study the relationship between intellectual capital and investment opportunities on selected firms listed on Tehran Stock Exchange (TSE) over the period 2005-2011. In our survey, Tobin Q represents investment opportunity and intellectual capital is measured based on different variables such as value added intellectual capital and human capital. The study uses regression technique with panel data and random effect and the results indicate that there was no meaningful relationship between intellectual capital and investment opportunity. In other words, most investment opportunities on TSE do not depend on intellectual capital and they mostly depend on traditional methods of investment.

\section{Introduction}

During the past few years, there have been tremendous efforts on the measurement of intellectual capital (IC) within the field of knowledge management (Luthy, 1998; Fama \& French, 1998; Griffiths et al., 2005). Organizational knowledge is at the crux of sustainable competitive advantage, the burgeoning field of IC is an exciting area for many researchers since it is conceptualized from various disciplines making the field a mosaic of perspectives. Many financial accountants are interested in measuring it on the balance sheet, information technologists normally wish to codify it on systems, sociologists plan to balance power with it, psychologists look for development of minds because of it, human resource managers are always after calculating an ROI on it, and training and development officers plan to make sure that they could build it (Bontis, 1999).

Sydler et al. (2013) presented a technique to measure IC to find out whether IC supports the knowledge-based view of the firm, which describe long-term differences in firm profitability. They systematically investigated the landscape of IC valuation techniques used and addressed in the literature, and presented one technique by choosing monetary proxies for human, structural and

*Corresponding author. Tel: +989121996121

E-mail addresses: shiva.tavakoli86@gmail.com (S. Tavakoli) 
relational capital. They also presented a longitudinal panel data regression based on 69 publicly traded pharmaceutical and biotechnology firms over the period 2002- 2009. They reported that ICcreating expenses indeed could produce IC assets in a subsequent year and that an increase in IC was associated with a higher return on assets over time. They also showed that all three factors independently could lead to the generation of IC and more importantly, their interaction. In addition, they described some implications for knowledge management theory and practice and presented a new method to evaluate the IC based on easy accessible data and to verify its effect on firm performance. Furthermore, it provided a tool for managers to measure the value of a company's IC directly and judged its effect on firm performance.

According to Casey (2010), Intellectual capital (IC) is considered a primary concept for sustaining a global livestock industry. The major challenge is to develop IC to describe the negative influences of the livestock industry, yet continue the advances towards more effective livestock production. Investments in IC to keep the livestock industry are not only technical instrument, but also it includes external constituencies such as customers and different other associated entities. IC for the livestock industry is needed at various levels that range from laborers to university science graduates. Jørgensen et al. (2006) considered a new firm in the IT industry, established by a management team and partially financed by venture capital. Abdolmohammadi (2005) developed a descriptive framework of the components of intellectual capital in annual reports and investigated the impacts of disclosure of intellectual capital on market capitalization. The study reported that the frequency of disclosure of information about brand and proprietary processes had increased over the study period.

Arenas and Lavanderos (2008) analyzed the epistemological foundations associated with the concept of IC. They explained that various researchers on IC had agreed on the issue that knowledge could generate sustainable competitive advantage. They reported that the cognitive sciences could contribute guidance in the face of the implications of including IC within the domain of representation. Sudarsanam et al. (2006) performed an empirical investigation on real options and the impact of intellectual capital on corporate value. Ileanu and Tanasoiu (2008) investigated on factors of the earning functions and their influence on the intellectual capital of an organization. Bontis (1998) performed an investigation on IC as an exploratory study that develops measures and models. Bontis (2001), in other assignment, presented a review on the IC measurement models.

\section{The proposed study}

This paper presents an empirical investigation to study the relationship between intellectual capital and investment opportunity on selected firms listed on Tehran Stock Exchange (TSE) over the period 2005-2011. In our survey, Tobin Q represents investment opportunity and intellectual capital is measured based on different variables such as value added intellectual capital and human capital. There are six main hypotheses and three sub-hypotheses associated with the proposed study of this paper as follows,

1. Main: hypothesis: There is a meaningful relationship between investment opportunities and intellectual capital.

1.1. There is a relationship between investment opportunities and capital used $\left(C E E_{i, t}\right)$.

1.2. There is a relationship between investment opportunities and human capital efficiency $\left(H C E_{i, t}\right)$.

1.3.There is a relationship between investment opportunities and efficiency of capital structure $\left(S C E_{i, t}\right)$.

2. The relationship between investment opportunities and intellectual capital in bigger firms is stronger than smaller ones. 
3. The relationship between investment opportunities and intellectual capital in firms with bigger leverage is stronger compared with firms with smaller leverage.

4. The relationship between investment opportunities and intellectual capital in firms with bigger profit distribution is stronger compared with firms with smaller profit distribution.

5. The relationship between investment opportunities and intellectual capital in firms with bigger investment costs is stronger compared with firms with smaller investment costs.

6. The relationship between investment opportunities and intellectual capital in firms with bigger profits is stronger compared with firms with smaller profits.

The proposed study uses the following regression model to examine various hypotheses of the survey.

$I O_{i t}=\beta_{0}+\beta_{1} V A I C_{i t}+\beta_{2} S I Z E_{i t}+\beta_{3} L E V_{i t}+\beta_{4} D P O_{i t}+\beta_{5} I N V_{i t}+\beta_{6} P R O F_{i t}+\varepsilon_{i t}$

where $I O_{i t}$ represents investment opportunities, $V A I C_{i t}$ denotes value added intellectual capital, SIZE $E_{i t}$ states the size of the firm, $L E V_{i t}$ is associated with leverage of the firm, $D P O_{i t}$ denotes dividend per share, $I N V_{i t}$ represents investment costs and finally $P R O F_{i t}$ denotes total net profit of firms. The study uses regression technique with panel data and random effect. Next, we present the summary of our findings.

\section{The results}

In this section, we present details of our findings on testing various hypotheses of the survey. Table 1 demonstrates the summary of our results.

\section{Table 1}

The summary of testing various hypotheses

\begin{tabular}{|c|c|c|c|c|c|c|c|c|c|c|}
\hline \multirow[t]{2}{*}{ Variable } & \multicolumn{2}{|c|}{$S I Z E_{i, t}$} & \multicolumn{2}{|c|}{$L E V_{i, t}$} & \multicolumn{2}{|c|}{$\begin{array}{l}\text { Criteria for firm seperation } \\
\qquad D P O_{i, t}\end{array}$} & \multicolumn{2}{|c|}{$I N V_{i, t}$} & \multicolumn{2}{|c|}{$P_{R O F_{i, t}}$} \\
\hline & Low & High & Low & High & Low & High & Low & High & Low & High \\
\hline$C E E_{i, t}$ & $\checkmark$ & $\checkmark$ & $\checkmark$ & $x$ & $\checkmark$ & $\checkmark$ & $\checkmark$ & $\checkmark$ & $\checkmark$ & $x$ \\
\hline$H C E_{i, t}$ & $\checkmark$ & $x$ & $x$ & $x$ & $x$ & $x$ & $x$ & $x$ & $x$ & $\checkmark$ \\
\hline$S C E_{i, t}$ & $x$ & $x$ & $\checkmark$ & $x$ & $x$ & $x$ & $x$ & $x$ & $x$ & $x$ \\
\hline Coefficient & 0.052592 & 0.154363 & 0.251658 & 0.014618 & 0.59882 & 0.32074 & 0.093919 & 0.052247 & 0.489569 & 0.110405 \\
\hline Stronger & & $\checkmark$ & $\checkmark$ & & $\checkmark$ & & $\checkmark$ & & $\checkmark$ & \\
\hline
\end{tabular}

As we can observe from the results of Table 1, except the second hypothesis, which is associated with the size of the firms none of other hypotheses have been accepted. In other words, the relationship between investment opportunities and intellectual capital in bigger firms is stronger than smaller ones. However, other variables including leverage, profit distribution, etc. are not playing any role for investors who wish to use their intellectual capital to find investment opportunities. In addition, the study has found some meaningful relationship between investment opportunities and capital used.

\section{Conclusion}

In this paper, we have presented an empirical investigation to find the relationship between intellectual capital and investment opportunities on some firms listed on Tehran Stock Exchange over the period 2005-2011. The proposed study has examined six hypotheses and the results have indicated that only the size of the firms play an important role on relationship between intellectual capital and investment opportunities. In other words, our survey has indicated that bigger firms provide better opportunities for investors to use their intellectual capital for investment opportunities. The results of our survey clearly indicate that most investors on stock market still make their investment decisions based on traditional methods and not based on their intellectual capital, which is on the contrary to similar results reported on other exchange. 


\section{Acknowledgement}

The authors would like to thank the anonymous referees for constructive comments on earlier version of this paper.

\section{References}

Abdolmohammadi, M. J. (2005). Intellectual capital disclosure and market capitalization. Journal of intellectual capital, 6(3), 397-416.

Arenas, T., \& Lavanderos, L. (2008). Intellectual capital: object or process?. Journal of Intellectual Capital, 9(1), 77-85.

Bontis, N. (1998). Intellectual capital: an exploratory study that develops measures and models. Management decision, 36(2), 63-76.

Bontis, N. (1999). Managing organisational knowledge by diagnosing intellectual capital: framing and advancing the state of the field. International Journal of technology management, 18(5), 433462.

Bontis, N. (2001). Assessing knowledge assets: a review of the models used to measure intellectual capital. International journal of management reviews,3(1), 41-60.

Casey, N. H. (2010). Integrated higher learning-An investment in intellectual capital for livestock production. Livestock Science, 130(1), 83-94.

Fama, E. F., \& French, K. R. (1998). Value versus growth: The international evidence. The Journal of Finance, 53(6), 1975-1999.

Griffiths, W. E., Jensen, P. H., \& Webster, E. (2005). The effects on firm profits of the stock of intellectual property rights. Melbourne Institute of Applied Economic and Social Research.

Ileanu, B. V., \& Tanasoiu, O. E. (2008). Factors of the earning functions and their influence on the intellectual capital of an organization. Journal of applied Quantitative methods, 366.

Jørgensen, S., Kort, P. M., \& Dockner, E. J. (2006). Venture capital financed investments in intellectual capital. Journal of Economic Dynamics and Control,30(11), 2339-2361.

Luthy, D. H. (1998, August). Intellectual capital and its measurement. In Proceedings of the Asian Pacific Interdisciplinary Research in Accounting Conference (APIRA), Osaka, Japan (pp. 16-17). Brookings Institution.

Sydler, R., Haefliger, S., \& Pruksa, R. (2013). Measuring intellectual capital with financial figures: Can we predict firm profitability?. European Management Journal.

Sudarsanam, S., Sorwar, G., \& Marr, B. (2006). Real options and the impact of intellectual capital on corporate value. Journal of intellectual capital, 7(3), 291-308. 